\title{
Tumpang Tindih: Sebuah Komposisi Musik Dalam Interpretasi Personal
}

\author{
Warsana $^{1}$ \\ Jurusan Ethnomusikologi, Fakultas Seni Pertunjukan, Institut Seni Indonesia Yogyakarta
}

\begin{abstract}
ABSTRAK
Komposisi musik ini merupakan bagian dari relfeksi pengalaman masa kecil penulis ketika harus menghafal huruf Jawa Hanacaraka. Sebagai rangsang awal dalam karya ini adalah ide dari legenda Ajisaka tentang menciptakan huruf Jawa Hanacaraka. Ketidakpastian dalam satu keputusan memunculkan keputusan baru adalah gambaran tatanan kehidupan dewasa ini oleh karena bahasa serta sikap dalam mengambil tindakan yang tumpang tindih. Dalam komposisi ini Hanacaraka yang terdiri dari 20 kata diaktualisasikan ke dalam beberapa instrumen musik dan sumber bunyi dengan karakter yang berbeda. Komposisi ini memadukan instrumen gong, bonang, pralon, othokothok, klonthongan sapi, serta pengolahan huruf Jawa Hanacaraka. Komposisi ini memperhatikan tiga elemen musik yakni ritme, melodi, dan harmoni dengan pola permainan sukat yang berbeda. Penyajian komposisi sebagai sebuah pertunjukan dapat dinikmati secara audio maupun visual. Oleh karena itu, diperlukan penggarapan baik penyajian musikal maupun non musikal. Dengan mengacu pada pertunjukan teater maka diperlukan stage, agar terjadi komunikasi antara penonton dengan pemain dalam satu arah pandang mata.
\end{abstract}

Kata kunci: tumpang tindih, hanacaraka

\section{ABSTRACT}

The Tumpang Tindih: A Music Composition. Observing the current reality of twisted, overlap, and unstructured life becomes the theme of this composition. Music composition entitled "Overlapping" represents the part of the writer's reflective experience on his childhood when he must memorize Javanese letters of Hanacaraka. The difficulty in learning and memorizing the Javanese letters becomes the basic idea of the birth of his composition. The Legend of Ajisaka about creating the Javanese letters of Hanacaraka becomes the stimulus of an early idea in this composition. The uncertainty in one decision which emerges another new decision is a description of life arrangement nowadays because of the overlapping of the language and attitude. In this composition, Hanacaraka with 20 letters is actualized into some musical instruments and sound with different characters. This composition combines the gong instrument, bonang, "pralon"- hard pipe, othokothok - a traditional children's toy, "klontongan sapi"- the bell horn by the ox, and also the Javanese letters of Hanacaraka arrangement. All the sound mentioned above; then is composed into three music elements, namely the existence of rhythm, melody, and harmony with different "sukat"- measure such as 3/4, 4/4, 5/4, 7/4. This composition is presented as a performance, which can be appreciated through audio and visual. Therefore, a good musical and non-musical arrangement is necessarily used. Referring to the theatre performance, hence a stage is needed in order to be a direct communication media for the audience and players.

Keywords: overlapping, hanacaraka

\section{Pendahuluan}

Tumpang tindih dalam tulisan ini adalah sebuah catatan karya musik yang tercipta berdasar pengalaman pribadi yang bersifat personal dan bersumber dari kejadian atau peristiwa baik secara musikal atau non musikal. Realitas kehidupan sehari-hari seperti: keluarga, lingkungan, masa kecil, fenomena alam, bencana, sosial, budaya, politik maupun fenomena musikal yang berasal dari berbagai ragam musik adalah segudang bahan yang dapat dijadikan ide atau gagasan berkarya. Bercampuraduknya permasalahan dari berbagai macam persoalan sering terjadi dalam kehidupan sehari-hari menjadi sumber insprirasi dan memicu kegelisahan penulis untuk menciptakan karya ini.

Tumpang Tindih berarti bersusun-susun, bertumpuk-tumpuk, bercampuraduk, saling berbeda (Kamus Besar Bahasa Indonesia, 2005: 1222), melatarbelakangi terlahirnya sebuah tema garapan dalam komposisi musik ini. Pengalaman hidup sehari-hari yang campur aduk, silih berganti, tumpang tindih tak teratur, mengalir seiring dengan waktu. Dari jam ke jam dari menit ke menit, kita mengalami pengalaman hidup di dunia ini (Jakob Sumarjo,2000:146). Hidup yang demikian itu menyeret diri penulis, mau tak

1 Alamat koresponden: Prodi Etnomusikologi ISI Yogyakarta. Jalan Parangtritis KM 6,5 Sewon, Yogyakarta. HP: E-mail: kliwir_kdg@yahoo.com. 
mau untuk mengamatinya, memikirkannya dan menilainya hingga mengkristal menjadi sebuah gagasan, konsep berpikir untuk mengembangkan lebih jauh menjadi sebuah komposisi musik.

Tumpang tindih ini termasuk di dalamnya bagaimana penulis mendayagunakan alam ide dan alam sekitar manakala melihat kenyataan yang terjadi saat ini, yakni masih banyak khususnya anak-anak muda yang sudah tidak mengenal lagi huruf atau aksara Jawa. Aksara adalah hal yang sangat penting dalam berbahasa, karena dari rangkaian aksara itulah tersusun kata demi kata yang biasa dipakai dalam berbahasa. Ketidakjelasan dalam berbahasa memungkinkan seseorang tidak paham akan maksud dan tujuan yang hendak disampaikannya. Bahkan yang lebih fatal dengan tidak pahamnya seseorang terhadap bahasa yang dikomunikasikan lawan bicaranya, akan terjadi salah persepsi, sehingga maksud terhadap apa yang diucapkan tidak sampai.

Aksara Jawa terkesan hanya milik kaum tua, sementara anak-anak lebih dituntut untuk mengenal abjad yang ada dalam bahasa Indonesia atau bahkan mengenal huruf-huruf lain yang berkembang dewasa ini. Hal ini menjadikan sebuah tanda tanya dalam diri penulis bagaimana mungkin anak-anak lebih banyak diajarkan untuk mengenal huruf Arab, China, Inggris atau yang lain, sementara mereka hidup di kalangan masyarakat Jawa. Dalam kehidupan sehari-hari mereka terbiasa dengan menggunakan bahasa Jawa, akan tetapi mereka jarang mengenal lebih dalam tentang huruf-huruf yang ada dalam bahasa Jawa tersebut.

Tumpang tindih merupakan satu proses susun menyusun di antara beberapa perbedaan baik beragam instrumen yang dipilih mupun cara menginterpretasi dan memusikalisasi huruf Jawa ke dalam beragam instrumen tersebut. Memberikan aksentuasi yang berbeda dalam pengucapan huruf-huruf Jawa tersebut dan adanya kesengajaan untuk membalik urutan cara pengucapan huruf Jawa menjadi "Caraka Balik".

Sebagaian masyarakat percaya bahwa dalam pengucapan huruf-huruf Jawa $\mathrm{Ha} \mathrm{Na} \mathrm{Ca} \mathrm{Ra} \mathrm{Ka}$ ketika cara pengucapannya di balik dari urutan belakang maka masyarakat mengenalnya dengan Caraka Balik. Caraka Balik dapat digunakan sebagai mantra dan pemusnah perbuatan jahat dan fitnah dari pihak lain (Riyadi, 1996: 47).

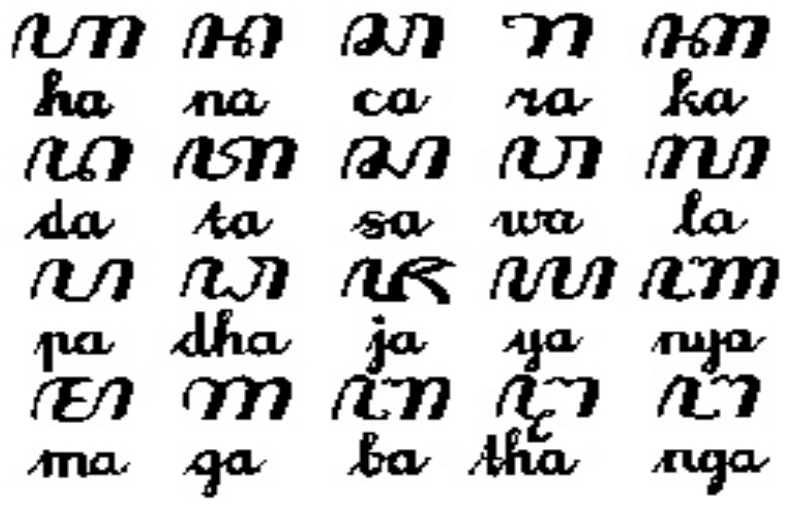

Gambar 1. Aksara Jawa

Akan tetapi di dalam komposisi ini lebih menekankan pada sumber ciptaan yang mengacu pada huruf Jawa $\mathrm{Ha} N a \mathrm{Ca} R a \mathrm{Ka}$, untuk dapat diolah menjadi rangkaian katakata dengan memberikannya nada-nada dalam kata-kata tersebut agar lebih mudah diingat dan dipahami. Ritme, melodi, harmoni dan dinamika membingkai rangkaian kata-kata dalam huruf Jawa $\mathrm{Ha} \mathrm{Na} \mathrm{Ca} \mathrm{Ra} \mathrm{Ka}$ dipadukan beragam instrumen dan birama yang berbeda mampu menyampaikan arti atau makna tertentu sebagai tema atau gagasan yang ingin dikomunikasikan. Semua hal tersebut merupakan proses kreativitas yang berawal dari pengalaman pribadi itu sendiri.

Tumpang tindih dapat pula diartikan sebagai tumpukan atau susunan antara gagasan ide dengan media yang beragam, baik instrumen maupun ide yang melatarbelakangi gagasan ini, untuk kemudian dituangkan kedalam komposisi yang tidak terikat pada pola tradisi. Tumpang tindih merupakan komposisi musik lebih bersifat bebas, artinya memberikan keleluasaan bagi penulis untuk melepaskan diri dari pijakan tradisi. Penggarapan komposisi ini tidak berangkat dari bentuk gending yang telah ada, bahkan lebih pada pendekatan kontemporer sehingga dalam konsep penyajiannya pun tidak seperti sajian dalam aturan konvensional. Dalam penyajian komposisi tumpang tindih tidak akan dijumpai cengkok, wiled, sekaran sebagaimana dalam idiom tradisi, meskipun media atau instrumen yang digunakan menggunakan alat-alat musik tradisi seperti kempul, bonang, rebana.

Pendekatan yang dipilih dalam komposisi ini adalah pendekatan kontemporer yakni mencipta karya yang berupaya membebaskan diri dari segala aturan-aturan konvensional yang berlaku 
pada genre musik, permainan instrumen, dan hal-hal konvensional lainnya. Sehingga dalam menciptakan karya ini penulis membebaskan diri dalam mengolah dan menginterpretasikan karya yang diciptakan tanpa harus terbebani aturan-aturan yang ada dalam tradisi. Melalui komposisi tumpang tindih, mencoba menuangkan pengalaman, menyalurkan perasaan, sehingga orang lain dapat merasakan atas apa yang bergejolak dalam diri penulis. Melalui komposisi ini sepenuhnya ingin mengungkapkan pengalaman yang dirasa selama ini dalam melihat dan merasakan tentang kehidupan yang tumpang tindih.

\section{Landasan Penciptaan}

Ide atau gagasan dapat muncul dengan sendirinya atau karena adanya rangsang awal yang dapat ditemukan oleh si seniman itu sendiri. Jacqueline Smith (1985: 20-22) berpendapat bahwa rangsang awal adalah sebagai langkah awal di dalam mencipta atau berkarya. Rangsang awal yang dimaksudkan adalah meliputi rangsang dengar (auditif), rangsang penglihatan (visual) rangsang gerak (kinestetik), rangsang peraba dan rangsang gagasan atau idea. Lebih lanjut I Wayan Senen (2002: 95) mengatakan bahwa lahirnya sebuah karya didasari oleh adanya rangsang visual, rangsang auditif, rangsang idea, dan rangsang musikal. Begitu pula halnya lahirnya karya musik tumpang tindih oleh karena adanya visual yang lebih dulu menginspsirasi.

Tumpang Tindih diilhami ketika melihat pemasangan spanduk di perempatan sudut jalan, tampak terlihat jelas betapa tidak teraturnya cara pemasangan sepanduk tersebut. Pengguna jalan dipaksa untuk melihat spanduk dengan beragam warna dan tujuan yang berbeda dalam satu ruang (space) yang sama. Sehingga terkesan semrawut, tumpang tindih, mengesampingkan nilai estetis dan ujung-ujungnya yang penting maksud dan tujuannya bisa terbaca oleh masyarakat yang melihatnya.

Bangunan rumah dengan corak bersusunsusun, perpaduan antara bentuk kotak dan bulat, serta desain warna cat rumah yang beraneka warna penulis temukan ketika membuka internet. Penulis mencari griya unik dan di situ penulis temukan satu bangunan rumah yang berbeda dari bangunan rumah pada umumnya. Bangunan yang tersusun seperti kotak dan bulat tersebut ditata sedemikian rupa, sehingga terlihat unik, menarik, namun tampak kokoh. Bangunan ini menginspirasi lahirnya sebuah karya dengan perpaduan dari beragam unsur yang berbeda.

Dua rangsang visual dan pengalaman pribadi ketika penulis masih kecil diungkap kembali melalui ruang imajinasi atau idea menjadi landasan karya musik tumpang tindih diciptakan. Komposisi ini merupakan proses kreativitas personal dalam menuangkan ide melalui jalinan melodi, ritme, irama, timbre dan dinamika agar dapat dikomunikasikan dengan pendengar atau penonton. Cara-cara dalam berkomunikasi dan mengkomunikasikan ide atau gagasan di dalam perwujudan karya masing-masing personal jelas memiliki perbedaan dan keunikan. Seniman berbicara dan berkomunikasi bukan secara verbal, melainklan lewat rasa dalam bentuk simbolsimbol. Jika seniman musik maka sebagai bahasa yang digunakan adalah dengan bahasa musik seperti ritme, melodi, harmoni dan sebagainya. Hal ini terjadi karena di satu sisi musik dianggap sebagai sarana untuk mengungkapkan perasaan, di sisi lain musik dianggap dapat menggugah perasaan (Djohan, 2008: 49). Komposisi musik tidak mungkin dipisahkan dari gejolak perasaan penciptanya, sementara bagi mereka yang menyukai musik setiap rangkaian melodi, irama, timbre, dan dinamika sangat mungkin menimbulkan perasaan tertentu yang berbedabeda (Djohan, 2008:49).

Leonard B. Mayer seorang referensialis yang pandangan-pandangannya sangat popular menegaskan bahwa:

Setiap karya seni dipengaruhi oleh berbagai keadaan yang berkaitan dengan berbagai pilihan sang seniman selama dalam proses penciptaan karya seninya. Diantara berbagai pilihan itu bisa saja muncul dari innerself sang seniman itu sendiri, misal latar belakang pribadi dan latar belakang profesinya, kehidupan sehari-hari, bermacam-macam kepentingannya yang bersifat karakteristik dan individual, pengaruh-pengaruh dari seniman lainya yang sudah mengkristal di dalam dirinya sendiri, dan lain sebagainya (Bramantyo, 1999: 162).

Tumpang tindih adalah salah satu dari sekian banyak karya musik, sudah barang tentu 
kelahirannya adalah sebagai perwujudan atau manifestasi diri yang dilatarbelakangi oleh pengalaman pribadi maupun lingkungan yang mempengaruhi.

\section{Perwujudan Karya}

Pengolahan adalah proses perwujudan yang bukan sepenuhnya kreasi baru, proses ini bersifat peralihan di tengah, yang memasukkan unsurunsur baru ke dalam sesuatu yang telah ada atau pernah dilakukan dan bersifat "orisinal" atau asli (Djelantik,2004:67). Perwujudan atau bentuk dari komposisi tumpang tindih yang penulis sajikan adalah dengan menggunakan media tradisi akan tetapi diolah dalam kemasan atau sajian baru. Sumber bunyi dari beragam instrumen yang telah dipilih, selanjutnya dipadukan dengan rangkaian kata-kata dari unsur huruf Jawa Hanacaraka disusun menjadi satu kesatuan dengan konsep secara tumpang tindih, seperti yang ada dalam inspirasi bentuk bangunan rumah maupun pemasangan sepanduk. Dengan kata lain bahwa karya musik yang penulis sajikan adalah imajinasi dari sumber-sumber yang dijadikan inspirasi kemudian mengaktualisasikannya ke dalam alatalat musik yang beragam dan berbeda untuk diciptakan menjadi rangkaian melodi, ritme serta harmoni di dalam bermusik.

Mengacu pada keberagaman dan saling berbeda di antara satu dengan lainnya maka dipilihlah lima buah nada dalam bonang yakni nada 1235 , dan lima nada instrumen gong dengan nada 35612 , lima buah instrumen rebana, lima klonthongan sapi, lima pralon, dan lima buah othok-othok. Konsep serba lima yang penulis tawarkan ini adalah mengacu pada nilai keseimbangan hidup manusia dalam dimensi lima contohnya Panca Maha Bhuta yaitu lima kekuatan dalam alam semesta: air, api, tanah, udara, akasa (Bandem, 1986: 12). Juga konsep yang mengacu pada kiblat papat limo pancer yakni arah wetan (timur), kidul (selatan), kulon (barat), lor (utara) serta pancer (tengah). Tengah adalah pusat kosmos manusia Jawa. Arah kiblat ini juga terkait dengan perjalanan hidup manusia, yang hidupnya selalu ditemani oleh kadang papat lima pancer. Kadang papat yaitu kawah, getih, puser dan adhi ari-ari. Sementara pancer adalah ego, atau manusia itu sendiri (Swardi Endraswara, 2006: 54).
Dalam pengolahan lagu (melodi/ritme) penulis menggunakan teknik pengolahan elemen musik Barat antara lain: repetisi (pengulangan), sekuen (pemindahan ritme ke nada lain), imitasi (peniruan), augmentasi (pelebaran durasi), diminusi (penyempitan), inversi (pembalikan arah nada), dan interplasi (perombakkan jauh) (Prier: 1996, 20-40).

Sering kita jumpai sukat 2/4, sukat $3 / 4$ atau $4 / 4$ adalah sebuah kebiasaan akan tetapi dengan sukat lain seperti konsep komposisi yang akan penulis tawarkan mungkin menjadi sebuah alternative baru. Kreativitas ada perwujudan dalam pengertian produktivitas yaitu menghasilkan produk baru yang merupakan pengulangan dari apa yang ada pada pola sebelumnya (Djelantik, 2001: 69). meskipun terkadang berpikir mampukah hal itu penulis lakukan. Mengingat kemampuan yang ada pada diri penulis belum seperti seniman musik lain yang mempunyai segudang pengalaman dan kemampuan yang lebih. Akan tetapi penulis mencoba memberanikan diri untuk mencoba sejauh mana kemampuan yang ada pada diri penulis menghadapi tantangan dalam penggarapan ini.

Dalam penggarapan ini penulis mencoba menggabungkan di antara sukat yang telah ada maupun membuat sukat yang berbeda seperti sukat $7 / 4,3 / 4$ maupun $5 / 4$. Hal ini penulis dapatkan dari hasil renungan dan membaca buku untuk mengetahui tentang dimensi 7 dalam kehidupan. Perhitungan dalam dimensi 7 yaitu percaya adanya kekuatan serba tujuh dalam kehidupan, seperti sapta wara: senin, selasa, rabu, kamis, jumat, sabtu, minggu. Sementara konsep 3 penulis renungkan dalam dimensi serba tiga, bahwa kehidupan ini dipercaya adanya kekuatan serba tiga (tri loka): dunia bawah, dunia antara, dan dunia atas. Sedangkan konsep 5 yakni mempercayai kehidupan dalam dimensi serba lima (Bandem, 1986: 11-12).

Munculnya perbedaan sukat yang dilambangkan dalam beberapa dimensi tersebut, dengan sendirinya akan berpengaruh pula terhadap pukulan maupun motif ritme yang dihasilkan. Sehingga kesan atau pun rasa yang ditimbulkan sudah barang tentu akan berbeda pula. Hal ini dapat dimaknai bahwa dengan adanya perbedaan maka kita akan memahami setiap perbedaan itu dan menghargainya, karena masing-masing 
perbedaan mempunyai nilai yang terkandung di dalamnya.

Komposisi tumpang tindih menggunakan konsep bermain. Konsep bermain adalah satu dari sekian pilihan yang kiranya tepat untuk mewakili perasaan maupun segala permasalahan yang ada. Kebebasan untuk mengungkapkan perasaan baik kepenatan, bercanda, menangis dalam diri penulis mampu tercurahkan di dalam konsep ini.

Sebagaimana gambaran tentang anak-anak bahwa bermain memberikan peluang untuk mengembangkan aspek emosional anak yaitu melalui bermain anak mempunyai rasa memiliki, merasa menjadi bagian atau diterima dalam kelompok, belajar untuk hidup dan bekerja sama dalam kelompok dengan segala perbedaan yang ada. Dengan bermain dalam kelompok anak juga akan belajar untuk menyesuaikan tingkah lakunya dengan anak yang lain, belajar untuk menguasai diri dan egonya, belajar menahan diri, mampu mengatur emosi, dan belajar untuk berbagi dengan sesama. Dari sisi emosi, keinginan yang tak terucapkan juga semakin terbentuk ketika anak bermain imajinasi. Sehingga dalam komposisi ini pun disuguhkan tak jauh dari proses bermain, keterikatan satu sama lain saling melekat.

\section{Proses Penciptaan}

Setiap bentuk karya seni ditangkap dengan berbagai cara oleh perasaan kita, kemudian masing-masing tumbuh dari sebuah kebutuhan yang sama, untuk memberi substansi ekspresi terhadap perasaan-perasaan, gagasan-gagasan, wawasan-wawasan dan pengalaman-pengalaman. Kreativitas seseorang tidaklah sama, tergantung kebiasaan mengkreasi dan mengembangkan pengalaman serta mengimajinasi segala hal yang berkaitan dengan sumber inspirasinya untuk dapat menciptakan sebuah karya. Pengalamanpengalaman yang ada pada dirinya memberikan kesempatan bagi aktivitas untuk mengembangkan kreativitas dalam menciptakan sebuah karya.

Pengembangan kreativitas pada dasarnya, dapat diklasifikasikan menjadi tiga bagian utama yaitu eksplorasi, improvisasi dan komposisi. Masingmasing klasifikasi ini akan disesuaikan supaya sesuai dengan tingkat perkembangan seseorang. Untuk mempermudah dan mengembangkan kreasinya setiap orang harus memahami masingmasing aktivitas kreatif, dan mengetahui bagaimana mengembangkan masing-masing tipe aktivitas itu ke dalam bermacam-macam tingkatan pengembangan kreatif (Alma Hawkin, 2003: 2324).

\section{Eksplorasi}

Melalui ekplorasi ini kita akan dapat mengembangkan atau menentukan temayang akan diciptakan melalui ceritera-ceritera, ide-ide dan konsep yang ada. Kemudian berpikir, berimajinasi, merasakan, menanggapi dan menafsirkan tentang tema yang dipilih (Bandem, $2001: 6$ ). Keuletan mengeksplorasi ruang-ruang imajiner untuk mengambil ide-ide segar, keberanian untuk mencoba hal-hal baru dan menjelajah wilayahwilayah yang sering ditabukan atau "angker", serta kejelihan melihat wilayah-wilayah yang tak terlihat dengan cara pandang biasa (Dwi Marianto, 2006: 2) adalah proses kreatif yang penulis lalui untuk mendapatkan dan menemukan kedalaman materi dalam komposisi ini.

Proses dan kerja kreatif dalam berkesenian yang sebenarnya tidak pernah lepas dari imajinasi, rasa, dan pemikiran-pemikian yang menerobos, serta membebaskan orang dari belenggu teoritikal yang terkadang justru reduktif dan membekukan aliran ide-ide cemerlang yang hidup (Dwi Marianto, 2007:30). Langkah-langkah ini ditempuh sebagai upayadalammelakukan pengembaran, pengamatan secara mendalam untuk mendapatkan apa yang ada dalam ruang imajiner di dalam berekplorasi. Sebagaimana telah disebuitkan dalam proses kreatif, seniman tidak meniru atau menciptakan kenyataan sebagaimana adanya, melainkan menciptakan dunianya sendiri. Caranya, dengan menggabungkan antara kenyataan dan tiruan sehingga kita selalu terkoinsidensi di antara kedua faktor. Dalam hubungan inilah diperlukan interpretasi (Ratna, 2007:66).

Mengacu pada pendapat tersebut di atas maka, dalam mengamati berbagai macam kemungkinan yang ada pada subjek yang penulis kaji sebagai sumber penciptaan yakni huruf Jawa Hanacaraka, maka langkah awal yang akan penulis lakukan adalah dengan mengamati huruf-huruf itu untuk dikembangkan ke dalam alam ide dan memusikalisasikan dalam interpretasi personal atau diri pribadi. Mengamati dan memaknai setiap penggal kalimat yang terucap dari lafal $\mathrm{Ha} \mathrm{Na} \mathrm{Ca} R a \mathrm{Ka}$, selanjutnya menelusuri lebih 
dalam tentang makna yang terkandung dari dua puluh kata yang ada. Lebih terbuka dalam menganalisa dan mencermati secara teliti terhadap temuan yang kita dapatkan, maka akan memberi kemudahan untuk menghasilkan gagasan atau ide dari pengamatan tersebut.

Eksplorasi juga dilakukan terhadap instrumen yang menjadi pilihan penulis untuk dicermati tentang karakter suara yang dihasilkan. Karena dengan kematangan dalam mencermati dan mengamati secara detail terhadap beragam instrumen yang menjadi pilihanya, akan membantu menyatukan ide maupun media sebagai bahan penuangannya. Dalam tahap ini penulis mencermati terhadap beragam instrumen yang menjadi pilihannya, salah satunya adalah mencermati instrumen bonang maupun gong. Hal ini dilakukan dalam rangka mengamati secara detail untuk menemukan perbedaan karakter dari beberapa instrumen yang dipilih atau menemukan potensi-potensi bunyi di dalam instrumen itu sendiri.

Usaha untuk menemukan segala sesuatu berkaitan dengan instrumen itu, diharapkan dapat ditemukan beragam alternatif untuk ditindaklanjuti mengenai tema yang menjadi pilihannya. Melalui eksplorasi ini penulis menemukan beragam kemungkinan untuk memperkuat imajinasi dan mengembangkannya dalam melahirkan satu karya.

\section{Improvisasi}

Improvisasi memberikan kesempatan yang lebih besar bagi imajinasi, seleksi, dan mencipta dari pada tahap eksplorasi. Karena tahap improvisasi terdapat kebebasan yang lebih, sehingga jumlah keterlibatan diri dapat ditinggalkan. Kreativitas melalui improvisasi kadangkadang diartikan sebagi "terbang ke yang tak diketahui (Hawkins,1991:29). Inilah saatnya seorang pencipta mempergunakan simpanan imaji-imaji dan melahirkan dalam bentuk yang baru. Melalui improvisasi seseorang diberikan kebebasan dalam mengolah maupun menentukan apa saja yang jadi bahan pilihanya. Melepaskan ikatan yang membelenggu untuk bebas bergerak, merentangkan gagasan yang ada dalam idenya untuk mengepakkan sayap berkelana atas kemauan idenya, mengembangkan pikirannya untuk menuju alam bebas tidak terikat dalam satu ikatan. Kebebasan melakukan berbagai alternatif baik pada instrumen yang akan digunakan dalam merealisasikan karya atau pun mencoba hal-hal baru dari berbagai macam kemungkinan.

Setiapmanusiamempunyaitingkatpemahaman dan daya khayal yang berbeda tergantung dari pemahaman yang dimiliki. Tingkat ketajaman tergantung pada latar belakang dan proses kreatif yang melatarbelakanginya. Sehingga tidak akan sama antara manusia yang satu dengan manusia lainnya dalam mencapai proses kreatifnya.

Improvisasi juga dimaksudkan sebagai percobaan-percobaan, membedakan, mepertimbangkan, membuat harmonisasi, dan menemukan integritas dan kesatuan terhadap berbagai percobaan yang telah dilakukan (Bandem, 2001: 6). Sebagai pertimbangan improvisasi yang dimaksudkan tetap mengacu dalam harmonisasi artinya tetap menjadi bagian yang tidak berdiri sendiri tetapi masih dalam satu ikatan. Membedakan dan membuat kesatuan terhadap percobaan yang yang telah penulis lakukan agar dapat mempertimbangkan dalam karya yang diciptakan.

Penulis melakukan improvisasi dengan beberapa cara. Pertama adalah dengan menyusun 5 nada bonang terdiri dari nada 1, 2, 3, 5, 6 . Kemudian masing-masing nada dipegang satu orang untuk memainkan satu komposisi guna mencarai kepekaan rasa masing-masing pribadi yang berbeda untuk dapat menemukan satu kesatuan di dalam pribadi yang berbeda.

Teknik membuyikan dengan cara ditepak dengan tangan atau dengan alat pemukul akan berbeda pula warna suara atau karakter bunyi yang dihasilkan. Begitu pula karakter suara yang dihasilkan dengan memukul bukan bagian penconnya. Kemudian dari suara dan karakter yang dihasilkan tersebut kita kelompokkan ke dalam beragam motif pukulan yang berbeda. Misal nada 1 dengan motif pukulan

dalam beragam motif pukulan yang berbeda. Misal nada 1 dengan motif pukulan 11

$\overline{\overline{111}} \overline{\overline{.1 .1}} \overline{11}$, nada 2 dengan motif pukulan $2 \quad 2 \quad 2 \quad 2$, nada 3 


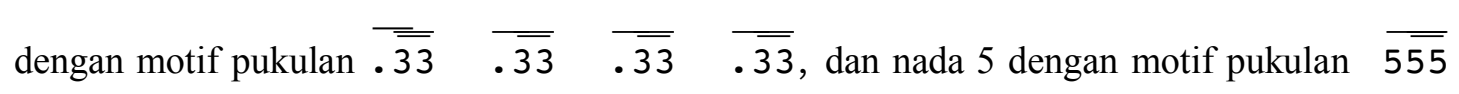

\section{$\overline{\overline{.5 .5}} \overline{5 \overline{55}} \overline{\overline{.5 .5}}$, dan nada 6 dengan motif pukulan $\overline{6 . \overline{6}} \overline{6 \overline{6.6}} \overline{6.6} \overline{6 . \overline{6}}$.}

Penjelajahan ini tidak terbatas pada pukulan terhadap penconnya, akan tetapi memukul bagian sisi-sisinya. Sehingga menghasilkan warna suara seperti lonceng.

Langkah kedua yang coba penulis lakukan adalah dengan melakukan improvisasi terhadap tubuh pemain itu sendiri. Memanfaatkan tubuh maupun vokal untuk mencari segala kemungkinan agar dapat diolah sehingga menghasilkan segala sesuatu yang tak terduga sebelumnya. Hal ini penulis lakukan dengan berharap dapat menemukan hal-hal baru untuk dikembangkan dan dikemas secara optimal. Salah satu yang ditemukan dalam improvisasi ini adalah menemukan ritme yang dihasilkan dari hentakan kaki, tepukan tangan, teriakan, dasah nafas dan hal-hal lain untuk dapat dijadikan salah satu motif pengembangan maupun tema dalam satu garapan.

Huruf aksara Jawa dapat pula dikembangkan untuk menemukan hal baru dalam improvisasi ini. Salah satunya adalah dengan mencoba membalikan urutan abjad huruf tersebut, sehingga dari bacaan: $\mathrm{Ha} \mathrm{Na} \mathrm{Ca} \mathrm{Ra} \mathrm{Ka} \mathrm{menjadi} \mathrm{Ka} \mathrm{Ra} \mathrm{Ca} \mathrm{Na} \mathrm{Ha}$

Memberikan nada-nada pada setiap kata yang coba dirangkai dari huruf aksara Jawa tersebut. Salah satu yang dapat penulis coba rangkai dan memberikan aksentuasi dari kata-kata tersebut adalah sebagai berikut:

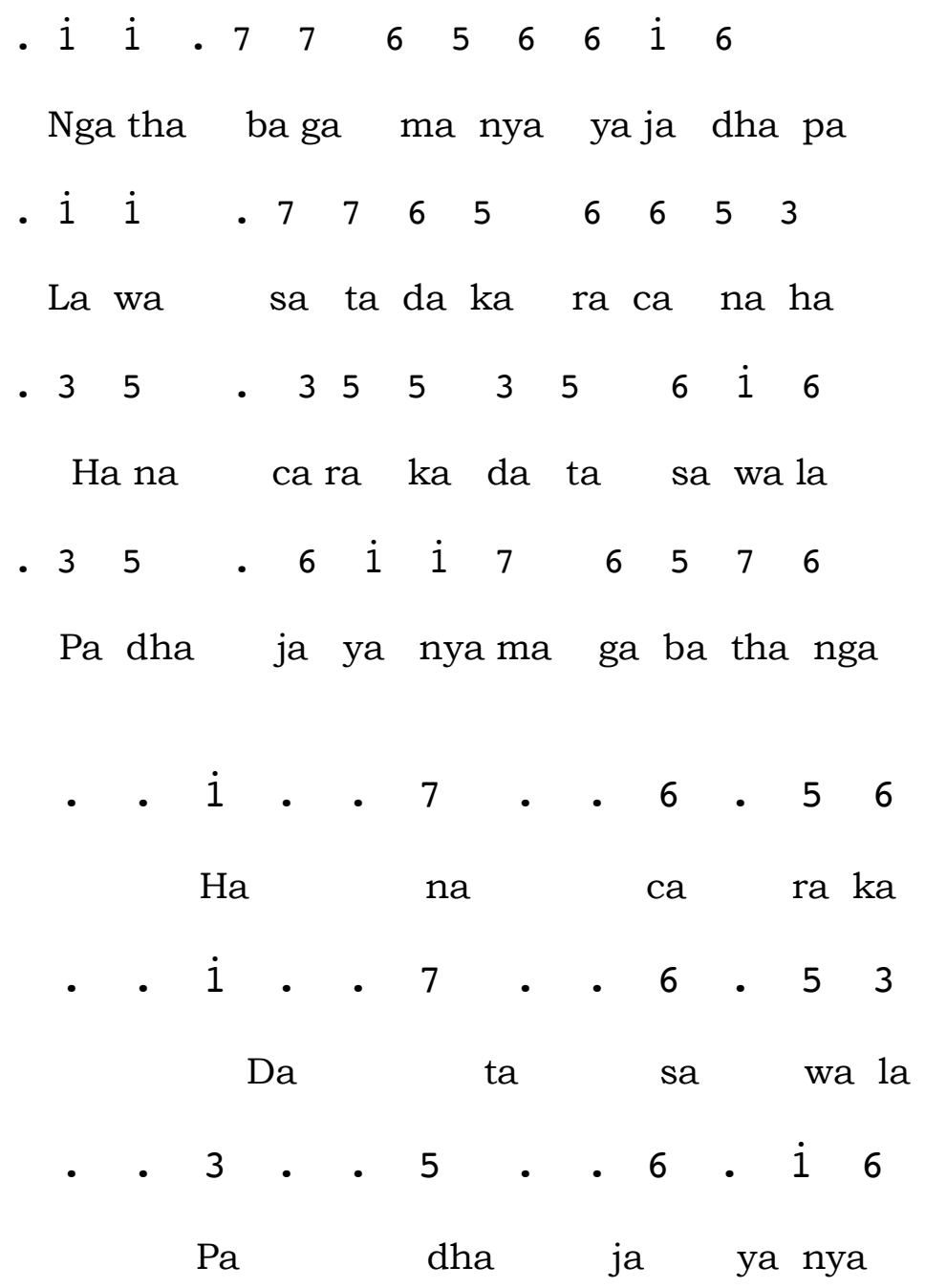


Improvisasi ini tentunya tidak akan berhenti sampai di sini masih banyak lagi warna suara yang dapat dimunculkan. Dengan variasi serta pengembaraan bunyi dari pencon gong. Mencoba memberika warna lain dengan meletakan instrumen gong tidak digantung akan tetapi disusun seperti pada penempatan instrumen bonang. Diberikan beberapa kelereng untuk menghasilkan warna dan karakter berbeda dari sebelumnya. Mencoba memindahkan pukulan rebana dan tabla di atas pencon gong. Mencoba memukul gong dengan tidak menggunakan pemukul seperti pada umumnya, akan tetapi dengan alat pemukul yang berasal dari rotan. Mencoba tidak harus memukukul bagian penconya, akan tetapi pada bagian sisinya atau bagian dalamnya. Hal ini penulis lakukan untuk mendapatkan segala kemungkinan yang dapat diolah dan dikembangkan dalam satu komposisi tersendiri dari instrumen gong tersebut. Sedangkan untuk percobaan terhadap instrumen bonang penulis memulainya dengan tidak memukul ke bagian penconnya akan tetapi pada badannya. Sehingga karakter suara yang dihasilkan bisa seperti lonceng maupun ceng-ceng.

Bagaimana dengan pralon? Sementara ini pralon lebih banyak digunakan untuk penyaluran atau pipa air. Akan tetapi di sini penulis mencobacoba dengan ditiup untuk menemukan karakter suara seperti suara sapi. Untuk menemukan karakter suara berbeda maka penulis mencoba untuk memotong agar suara yang dihasilkan berbeda dari pralon satu dngan pralon lainnya. Kemudian membuat ritme yang berbeda. Begitu seterunya terhadap klonthong sapi penulis melakukan percobaan untuk mencari perbedakan suara baik dengan bentuk secara fisik maupun suara yang dihasilkan. Dengan melakukan percobaan ini memungkinkan beberapa pola ritme yang dihasilkan berbeda. Improvisasi ini akan lebih banyak menemukan kemungkinan-kemungkinan yang sebelumnya belum ditemukan sudah barang tentu akan banyak menemukan karakter suara atau warna bunyi yang dihasilkanna tahap improvisasi terdapat kebebasan yang lebih, sehingga jumlah keterlibatan diri dapat ditinggalkan. Kreativitas melalui improvisasi kadang-kadang diartikan sebagi "terbang ke yang tak diketahui "(AlmaM. Hawkin, 2003:29) Inilah saatnya seorang pencipta mempergunakan simpanan imaji-imaji dan melahirkan dalam bentuk yang baru. Melalui improvisasi seseoang diberikan kebebasan dalam mengolah maupun menentukan ekspresi di dalam permainannya.

\section{Pembentukan atau komposisi}

Hasil dari perjalanan tentang proses adanya ekplorasi maupun improvisasi atau melakukan halhal yang sifatnya kreativitas dari seseorang, adalah dengan membentuk apa yang telah dilakukan selama ini. Merasakan, menghayalkan dengan ideide atau gagasan tanpa adanya suatu pembentukan atau komposisi yang diciptakan, maka hanya akan ada dalam angan-angan. Semua yang dilakukan oleh seorang seniman belumlah berarti apabila karya yang menjadi hasrat atau ungkapan tersebut belum berbentuk. Keseluruhan dari proses kreatif tersebut akhirnya terbentuk dalam satu komposisi dengan menggabungkan simbol-simbol yang dihasilkan dari berbagai percobaan, atau temuan sebelumnya yang telah dilakukan.

Beberapa aspek yang menjadikan karya tersebut menjadi indah di antaranya adalah meliputi keutuhan (unity), keseimbangan, kontras, penonjolan dan keterikatan satu sama lain. Komposisi tak dapat dipisahkan dari sisi-sisi estetis yang melekat dari setiap bagian yang ada dalam karya tersebut. Perjalanan panjang dari waktu ke waktu untuk dapat menciptakan sebuah karya yang indah adalah hal yang tidak mudah. Sehingga diperlukan kejelian dan keuletan untuk dapat menangkap dan memunculkan unsur-unsur keindahan di dalam komposisi itu sendiri.

Untuk dapat menciptakan keindahan dalam komposisi tumpang tindih penulis membagi dalam sembilan bagian. Pembagian ini dilakukan untuk mempermudah sekaligus menentukan dinamika. Masing-masing bagian saling mengikat antara bagian satu dengan bagian selanjutnya, meskipun di dalam satu bagian tersebut terdapat beragam warna yang dimunculkan sebagai mana tema yang dipilih yakni tumpang tindih.

Bagian awal adalah bagian pembuka (introduksi) yang diawali dengan masuknya anak kecil berpakaian SD berjalan dengan memainkan ritme kaki sambil membaca Hanacaraka dalam a. tempo. " $\mathrm{Ha} \mathrm{Na} \mathrm{Ca} \mathrm{Ra}$ Ka, Da Ta Sa Wa La, Pa Dha Ja Ya Nya, Ma Ga Ba Tha Nga. Kemudian terdengar teriakan "oeee...he! dan tepukan tangan serta hentakan kaki 


\section{$\overline{\cdot t} \overline{B t} \overline{B t} \overline{\overline{\cdot t} \cdot \bar{t}} \overline{t t} \overline{B t} \overline{B t} \overline{\overline{\cdot t \cdot \bar{t}}}(B) \overline{\cdot t} \overline{B t} \overline{B t} \overline{\overline{\cdot t} \cdot \bar{t}} \overline{t t} \overline{B t} \overline{B t} \overline{\overline{\cdot t \cdot \bar{t}}}$ B}

anak tersebut terlihat kebingungan untuk teman. Sesaat terdiam dan dilanjutkan untuk mencari arah suara yang ia dengar. Hal ini sebagai membaca caraka balik: Nga Tha Ba....Nga Tha gambaran penulis ketika harus belajar tetapi selalu $B a . . N g a$ Tha Ba Ga Ma. Muncul suara instrumen terpengaruh untuk ikut bermain dengan teman- bonang secara bergantian

Bonang nada $1: \overline{. c} \overline{1 \mathrm{c}} \overline{1 \mathrm{c}} \overline{\overline{. c} \cdot \mathrm{c}} \overline{\mathrm{cc}} \overline{1 \mathrm{c}} \overline{1 \mathrm{c}} \overline{\overline{. c} \cdot \bar{c}}(1)$ Bonang nada $2: \overline{. c} \overline{2 \mathrm{c}} \overline{2 \mathrm{c}} \overline{\overline{\cdot c} \cdot \mathrm{c}} \overline{\mathrm{cc}}$

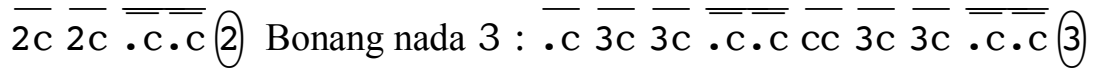

Bonang nada $5: \overline{. c} \overline{5 c} \overline{5 c} \overline{. c} \overline{. c} \overline{c c} \overline{5 c} \overline{5 c} \overline{. c} \overline{c c}(5)$ Bonang nada $6: \overline{\cdot c} \overline{6 c} \overline{6 c} \overline{. c} \overline{. c} \overline{c c}$

$\overline{6 c} \overline{6 c} \overline{\cdot c \cdot c}(6)$

kemudian muncul suara bonang yang dipukul dengan formasi kiblat papat lima pancer sebagai badanya menyerupai suara genta/lonceng. Para penanda akhir dari bagian satu untuk menuju pemain keluar sambil membaca Caraka Balik bagian dua.

[ "Nga Tha Ba Ga Ma...Nya Ya Ja Dha Pa...La Bagian dua dalam komposisi ini ditampilkan Wa Sa Ta Da...Ka Ra $\mathrm{Ca} \mathrm{Na} \mathrm{Ha”...]} \mathrm{diulang-} \mathrm{instrumen} \mathrm{bonang} \mathrm{dengan} \mathrm{pola} \mathrm{tabuhan}$ ulang untuk menuju stage. Setelah sampai di atas menyerupai sekatenan. Lima nada yakni 123 panggung pemain yang terdiri dari lima orang 56 tersebut masing-masing dipegang satu orang dengan pakaian seperti seorang bhiksu duduk pemain untuk memainkan satu komposisi.

\section{$33 \overline{23}, 1,33 \overline{23}, 1,33 \overline{23}, 5,3356,3356,6536,5$,

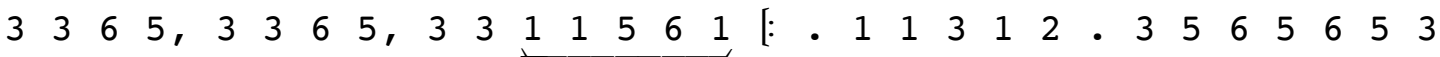 \\ $\begin{array}{lllllll:}6 & 5 & 6 & 5 & 3 & 2 & 1\end{array}$ :] diulang tiga kali kemudian fade in bonang}

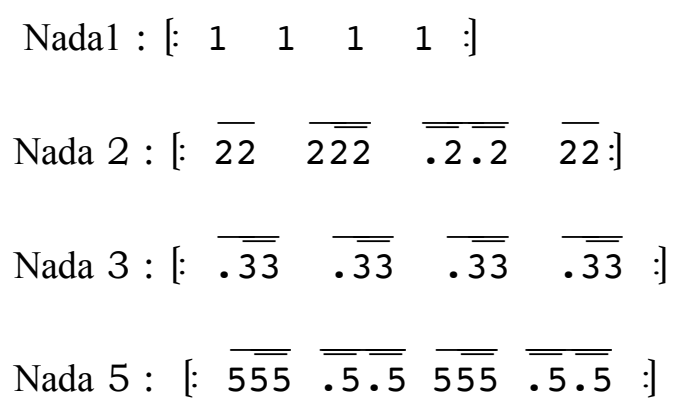




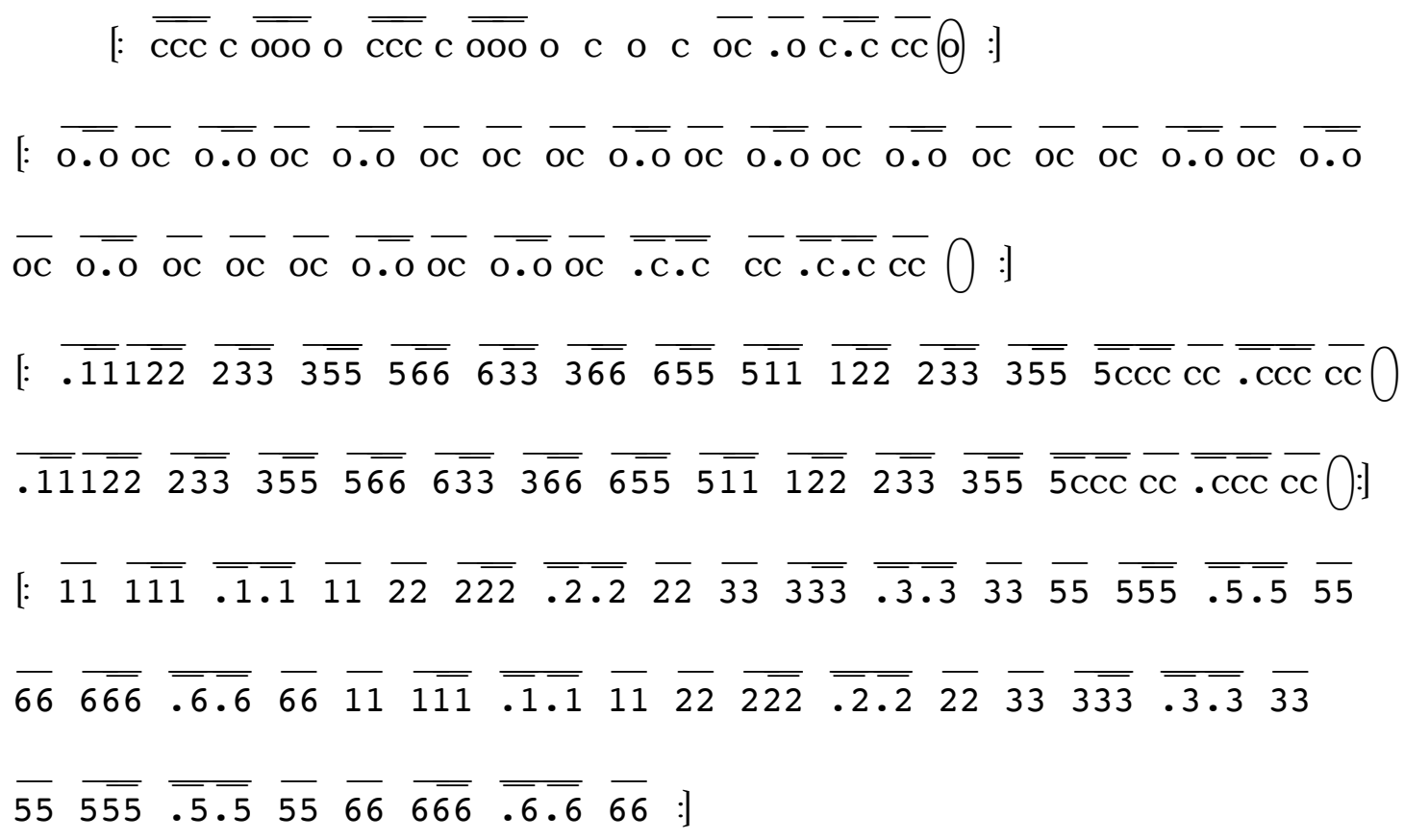

Kemudian secara bersama-sama (unisson)memainkan motif yang sama:

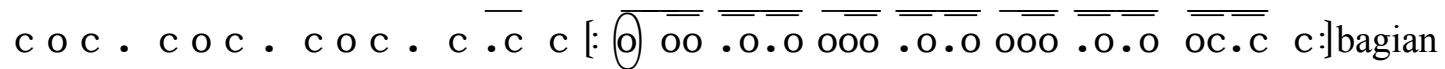
ini diulang empat kali. Motif ini diakhiri dengan aba-aba dari satu bonang sebagai tanda transisi $\overline{\overline{. \mathrm{c} . \mathrm{c}}} \overline{\mathrm{cc}} \overline{\overline{. \mathrm{c} \cdot \mathrm{c}}} \mathrm{c} \bigcirc$ selanjutnya fade in bonang satu persatu.

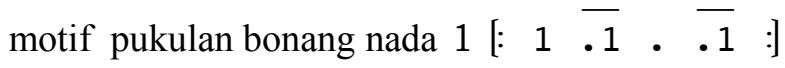

motif pukulan bonang nada $2[\because \quad \overline{. \overline{22}}, \overline{. \overline{22}}:]$

motif pukulan bonang nada $3\left[\begin{array}{lllll}: & - & 3 & 3 & 3\end{array}\right]$

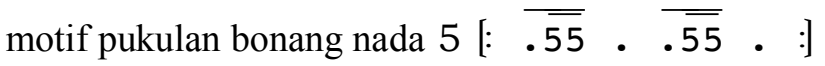

motif pukulan bonang nada $6\left[\begin{array}{llllll}: & \overline{66} & \overline{6 \overline{66}} & \overline{\overline{.6}} & & 6\end{array}\right]$

motif pukulan ini diulang-ulang dan berakhir dengan adanya transisi bonang $\overline{\cdot \mathrm{c}} \overline{\mathrm{ccc}} \overline{\overline{\cdot c} \cdot \mathrm{c}}$

$\overline{\mathrm{cc}} \odot$

motif pukulan bonang nada $1\left[\begin{array}{llllll}: & 1 & 1 & 1 & 1 & :]\end{array}\right]$

motif pukulan bonang nada $2\left[\begin{array}{llllll}: & \overline{22} & \overline{2 \overline{22}} & \overline{\overline{.2} .2} & \overline{22} & \text { : }\end{array}\right]$

motif pukulan bonang nada $3 \quad\left[\begin{array}{llllll}: & \overline{.33} & \overline{.33} & \overline{. \overline{33}} & \overline{.33} & \text { :] }\end{array}\right]$ 


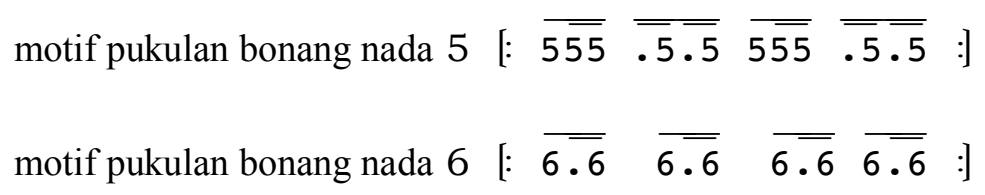

Bagian ini diulang beberapa kali hingga ada aba-aba bonang nada $6: \overline{66} \overline{6 \overline{66}} \overline{\overline{.6 .6}} 6 \odot$ sebagai tanda untuk menuju bagian selanjutnya.

\section{$\mathrm{Ga} \cdot .6 \quad 6.666$ \\ - Ga .. Ga Ga Le Nya}

Bagian tiga dalam komposisi ini adalah sebagai perwujudan kiblatpapatlima pancer untuk dimunculkannya vokal Hanacaraka dipadukan kemudian berputar melawan arah jarum jam. Hal dengan Caraka Balik dalam birama 3/4. Bagian ini dimaksudkan sebagai gambaran dari berpikir ini semua pemain berdiri dari tempat duduknya terbalik dari segala sesuatu yang sudah biasa untuk yang semula posisi empat arah yang berbeda hal-hal yang tidak biasa.

$$
\begin{aligned}
& {\left[: \begin{array}{llllllllllll}
\text { - } & \mathrm{i} & \mathrm{i} & \text { • } & 7 & 7 & 6 & 5 & 6 & 6 & \mathrm{i} & 6
\end{array}\right.} \\
& \text { Nga tha ba ga ma nya ya ja dha pa } \\
& \text {. } \begin{array}{lllllllllll}
i & i & . & 7 & 7 & 6 & 5 & 6 & 6 & 5 & 3
\end{array} \\
& \text { La wa sa ta da ka ra ca na ha }
\end{aligned}
$$

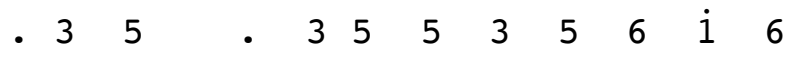

$$
\begin{aligned}
& \text { Ha na ca ra ka da ta sa wa la } \\
& \begin{array}{lllllllllll}
-3 & 5 & - & 6 & \mathrm{i} & \mathrm{i} & 7 & 6 & 5 & 7 & 6:]
\end{array} \\
& \text { Pa dha ja ya nya ma ga ba tha nga }
\end{aligned}
$$

Diulang dua kali dalam posisi masih duduk dan berputar melawan arah jarum jam sambil di tempat masing masing. Selanjutnya berdiri menyanyikan lagu berikut ini

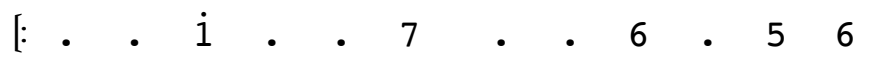

$$
\begin{aligned}
& \mathrm{Ha} \text { na ca ra ka }
\end{aligned}
$$

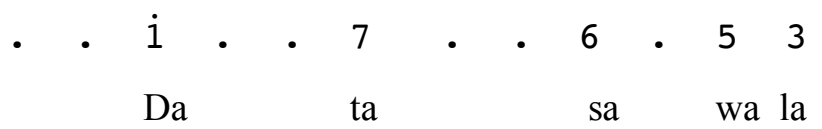

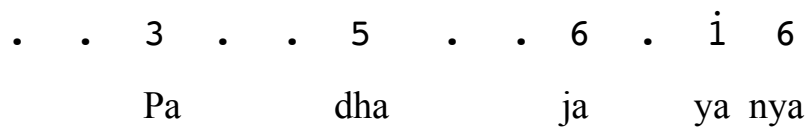

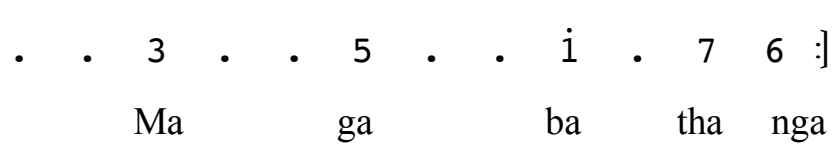


Lagu ini diulang dua kali, kemudian digabung ketika instrumen bonang tersebut sudah diletakkan dan diulang sebanyak dua kali. Kemudian secara di tempat instrumen (plangkan).

bersama-sama memukul bagian badan bonang,

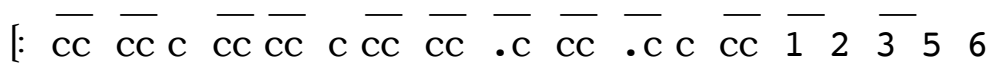

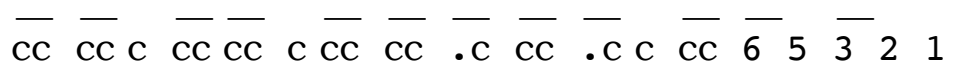

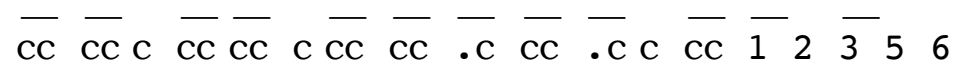

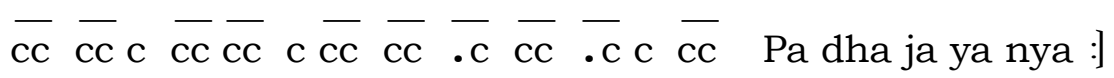

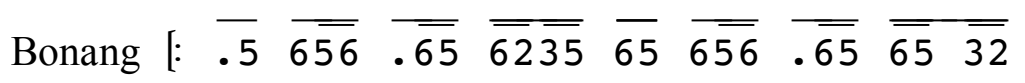

$$
\begin{aligned}
& \overline{15} \overline{656} \overline{. \overline{65}} \overline{\overline{6255}} 6 \overline{\overline{\mathrm{cc}} \overline{\mathrm{cc}}} \overline{. \overline{\mathrm{c}} \overline{\mathrm{cc}}} \mathrm{c}
\end{aligned}
$$

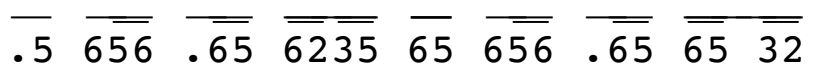

$$
\begin{aligned}
& \overline{15} \overline{6 \overline{56}} \overline{. \overline{65}} \overline{\overline{62} \overline{35}} \quad 6 \overline{\overline{\mathrm{cc}}} \overline{\mathrm{cc}} \overline{\overline{. c}} \overline{. \mathrm{c}} \mathrm{c}
\end{aligned}
$$

vokal

[: nga nga tha $\overline{\text { baga }} \overline{. \overline{\text { manya }}} \overline{\text { ya jadha }} \overline{\text { pala }} \overline{\text { wa sata }} \overline{. \overline{\text { daka }} \overline{\text { ra cana }}}$

$\overline{\text { ha ha }} \overline{\text { na cara }} \overline{. \overline{\text { kada }}} \overline{\text { ta sa wa }}$ la $\overline{\overline{\text { pa dha ja ya }}} \overline{\text { nya maga }} \overline{\text { ba tha }}$ :

$$
\overline{15} \overline{6 \overline{65}} \overline{. \overline{65}} \overline{\overline{62 \overline{35}}} \quad 6 \overline{\overline{\mathrm{cc}} \overline{\mathrm{cc}}} \overline{\overline{. c}} \overline{\overline{. c}} \mathrm{c} \odot
$$

$\overline{\text { sa dipe }}$ pet SE. $\overline{\text { pa diwu }}$ lu PI. sa dipe pet SE $\overline{\text { pa diwu }}$ lu PI

$\overline{\text { sa dipe }}$ pet $\overline{\text { pa diwu }}$ lu $\overline{\text { sa dipe }}$ pet $\overline{\text { pa diwu }}$ lu se pi se pi

$\overline{\overline{\text { sepi sendi }}} \overline{\text { ri tanpa }} \overline{\overline{\text { dia disi }}}$ ni

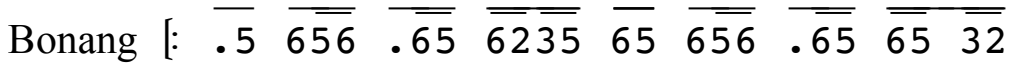

$$
\begin{aligned}
& \overline{15} \overline{6 \overline{56}} \overline{. \overline{65}} \overline{\overline{62} \overline{35}} \quad 6 \overline{\overline{\mathrm{cc}}} \overline{\overline{\mathrm{cc}}} \overline{\overline{. c}} \overline{. \mathrm{c}} \mathrm{c} \odot
\end{aligned}
$$




\section{klontong sapi 1: $\overline{\overline{\phi \phi} \overline{\phi \phi}}$ klonthong $2 \overline{\overline{\phi \phi} \overline{\phi \phi}}$ klonthong $3 \overline{\overline{\phi \phi} \overline{\phi \phi}}$ klonthong $4 \overline{\overline{\phi \phi} \overline{\phi \phi}}$}

klonthong $5 \overline{\overline{\phi \phi} \overline{\phi \phi}}$ diakhiri suara pralon . . . o0gon. . .

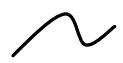

0000

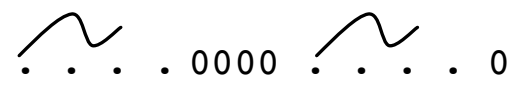

kemudian improvisasi tiupan pralon menyerupai suara sapi disertai suara klonthong. Selanjutnya suara manusia seakan-akan menggiring sapi " her...jo.jo...sessss haeh..haeh"

serta improvisasi dengan kata-kata. Transisi akan ditandai dengan kata " herrrr Jok . .Jok

. Jok Jok sebagai tanda menuju bagian berikutnya.

Bagian empat dalam komposisi ini adalah pola dari pemain yang memainkan instrumen tersebut. permainan dari instrumen pralon dan klontong Dengusan napas panjang dan ritmis sebagai akhir sapi. Bagian ini terdapat imbal baik klontong sapi dari bagian ini.

maupun pralon serta pola pukulan improvisasi

klonthong $1:[: t \cdot t \cdot t \cdot t \cdot t \cdot t \overline{\cdot t} \cdot \bar{\cdot} \cdot t \cdot t \cdot:]$

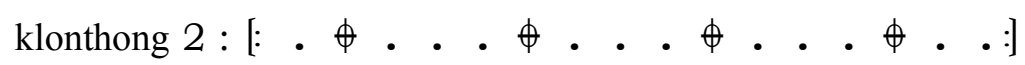

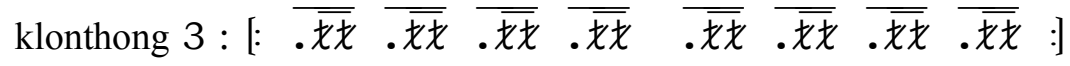

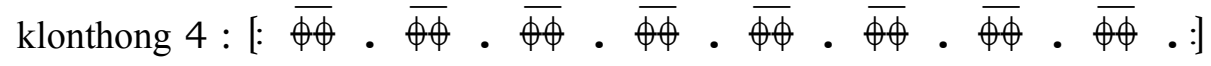

klonthong $5:[:$. • 由 . .

pralon $:[:$ • • • \ • • • \ :

diulang beberapa kali selanjutnya transisi ditandai dengan rool klonthong menuju motif berikutnya.

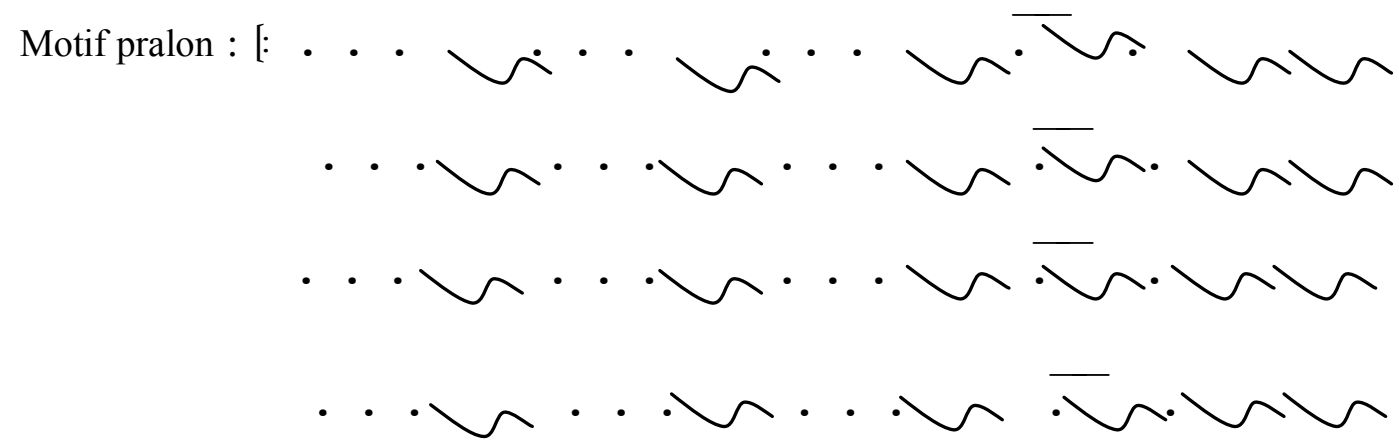


Transisi suara pralon panjang dan berubah motif tupannya menjadi imbal.

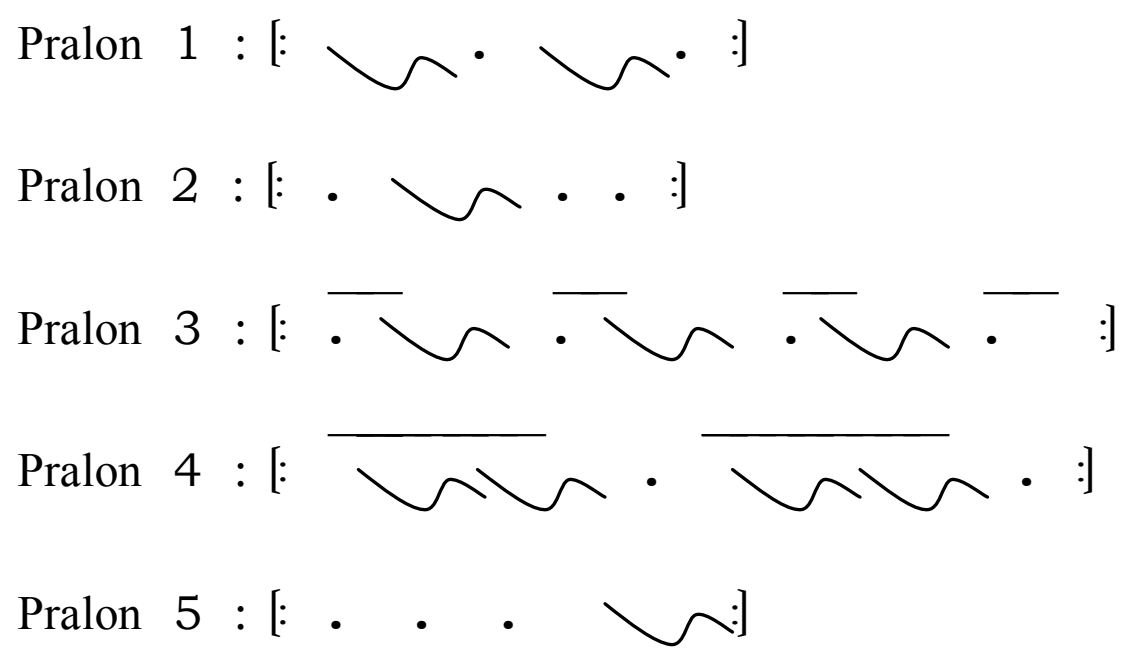

Transisi ini ditandai dengan suara tiupan membuat ritme dari nafas tersebut. Setelah itu panjang pralon kemudian helaan nafas panjang. Istirahat sebenter sambil mengambil nafas dan nafas dengan suara "Hah Huh" dengan motifnya improvisasi serta mengumpulkan tenaga untuk

[ • • • HAH • • • HUK • . . HAH HUK • HUK HAH :] diulang 4 kali

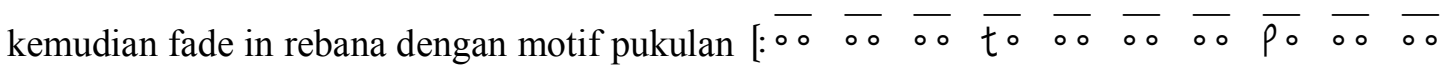
$\bar{\circ} t \quad P$. $P \overline{t \circ}:]$ diulang dua kali untuk memainkan motif berikutnya.

$$
\begin{aligned}
& \text { Motif } 1[\overline{\circ \overline{\circ P}} \overline{P P} \circ \mathrm{d} \overline{\circ \overline{\circ P}} \overline{P P} \circ \mathrm{d} \overline{\overline{\circ .}} \overline{P P} \circ \mathrm{d} \overline{\circ \overline{\circ P}} \overline{P P} \circ \mathrm{d} \\
& \overline{\circ \overline{. P}} \overline{P P} \circ d \overline{. t} \overline{d t} \overline{d t} d:]
\end{aligned}
$$

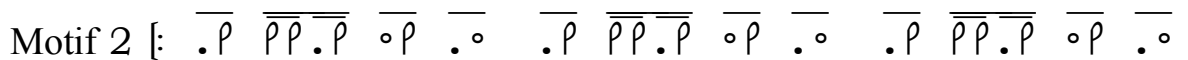

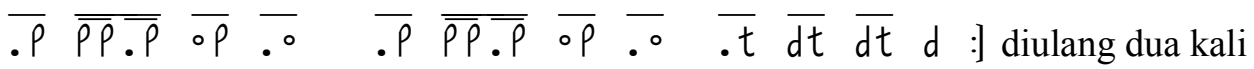

diakhiri dengan transisi pukulan rebana $t t d t t \quad t t \overline{d t} t$

$[: \bar{\circ} \overline{\circ \circ} \overline{\circ t} . \bar{\circ} \overline{\circ \circ} \overline{\circ t} . \bar{\circ} \bar{\circ} \overline{\circ t} \overline{. t} t . . . .8]$ diulang 2 kali 
Motif ini diimitatifkan ke dalam pola kecil apabila dilakukan secara bersama-sama akan tepukan tangan 2 kali. Selanjutnya motif tersebut saling mengikat satu sama lain. Kemudian pola dilakukan dengan satu jari, dua jari, tiga jari, dan gabungan antara tepukan tangan dengan tepakan empat jari. Dimaksudkan bahwa sesuatu yang rebana.

$$
[: \bar{\circ} \overline{\circ \circ} \overline{\circ p l a k} . \overline{\circ \circ} \bar{\circ} \overline{\circ p l a k} . \bar{\circ} \bar{\circ} \overline{\circ p l a k} \cdot \bar{p} \text { plak plak ... }
$$

Motif ini diulang dua kali.

$$
[: \overline{t t} \overline{t t} \overline{t p} \cdot \overline{t t} \overline{t t} \overline{t P} \cdot \overline{t t} \overline{t t} \overline{t P} \overline{\cdot \bar{P}} \rho . . . \quad \text {. d diulang dua kali. }
$$

Selanjutnya motif ini dimainkan dengan menggunakan stik dari rotan sebanyak empat kali

$$
\begin{aligned}
& \text { dengan transisi } \overline{t t} \overline{t t} \overline{t t} \cdot \overline{t t} \overline{t t} \overline{t t} \cdot \overline{t t} \overline{t t} \overline{t t} \cdot \bar{t} \overline{\overline{t t} \overline{t t}} \overline{\bar{t} \overline{t t}} t \text { HE! } t \\
& {[: \overline{\cdot t} \cdot t(t \overline{\cdot t} \cdot t(t \overline{\cdot t} \cdot t(t \overline{\cdot t} \cdot t \overline{\cdot t} \overline{t \overline{t t}} \overline{\overline{\cdot t} \cdot \bar{t}} t(t)] \text { diulang }}
\end{aligned}
$$

sebanyak empat kali dan diakhiri dengan rool rebana yang dipukul pakai stick rotan dengan pola pukulan unison $t+t t \overline{t t} \overline{t t} \overline{t t} \overline{t t} \overline{\overline{t t} \overline{t t}} \overline{\overline{. t} \overline{t t}} t$ HE ! diulang

vocal $\mathrm{Ha} \mathrm{Na} \mathrm{Ca} R a \mathrm{Ka}$ diucapkan secara bergantian.

Bagian lima adalah improvisasi untuk memainkan othok-othok Bagian ini mengadopsi dari permainan anak-anak. Oleh karena itu, semua pemain mengekspresikan pula dalam karakter seperti anak-anak. Dalam bagian ini kegembiraan muncul dari masing-masing pemain. Setelah beberapa saat kemuadian satu orang sebagai pemimpin memberi aba-aba untuk memainkan satu motif ritme othok-othok 65_3 56 . 65 $\begin{array}{lllllllllll} & 12 & 65 & 3 & 56 & 65 & 31 & .1 & \text { agar }\end{array}$ dilakukan berdasar pada kepemilikan othok-othoknya masing-masing. Motif ini diulang dua kali. Kemudian berekspresi gembira karena merasa benar dalam melakukan permainan tersebut. Selanjutnya satu orang sebagai pemimpin mengajak untuk memaminkan motif kedua yang

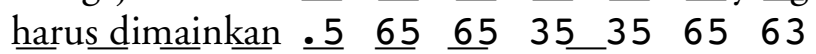
$\begin{array}{lllllllll}23 & 25 & 65 & 65 & 35 & 35 & 65 & 6 & 11 \\ \text { akan tetapi }\end{array}$ satu orang pemain sebagi perwakilan diri penulis selalu salah hingga akhirnya diusir untuk keluar dari permainan tersebut. Empat pemain masih tetap di atas stage untuk memainkan motif imbal dan motif bersama yang harus mereka mainkan.
Sambil jalan $[: t \quad t \quad \bar{t}$ krok] motif ini diulang-ulang hingga akhirnya satu orang pemain mengajak untuk diam sesaat dan meninggalkan penggung sambil lari dan membunyikan othokothok. Sebagai transisi untuk menuju bagian berikutnya.

Selanjutnya satu orang pemain dengan memakai seragam SD keluar dengan membawa othok-othok besar untuk memamerkan temantemannya. Akan tetapi stage sudah kosong tidak ada lagi teman-temanya. Kecewa, sedih, kesal bercampraduk dalam diri si anak tersebut sebagai akhir dari komposisi bagian ini. Selanjutnya anak tersebut mempuyai ide untuk memainkan kelereng dan instrumen gong sebagai sebagai sumber bunyi. Hal ini sebagai tanda untuk menuju bagian selanjunya.

Bagian enam sebagai pengembaraan bunyi untuk mencari kemungkinan-kemungkinan yang dapat ditemukan dengan pola permainan kelereng dan instrumen gong.

Kelereng:

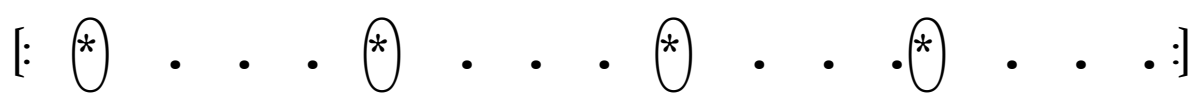


diulang-ulang dengan improvisasi pemain berdasar pada pengembaraan bunyi. Selanjutnya mencoba-coba melakukan hentakan kaki dengan mengadopsi permainan anak engkling $666 \mathrm{~B}$ bBB bB b bB. Dalam hal ini pemain dengan leluasa mencari sumber bunyi dari kaki, gong, maupun yang lain. Beberapa saat kemudian anak tersebut bosan dan memutar gong yang telah terisi kelereng untuk diputar dan ditumpahkan ke stage.

Suara kelereng yang diputar di dalam $* * * * * * * * * * * * * * * * * * * * * * * * *$ suara gong yang

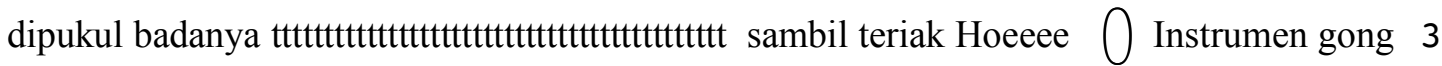

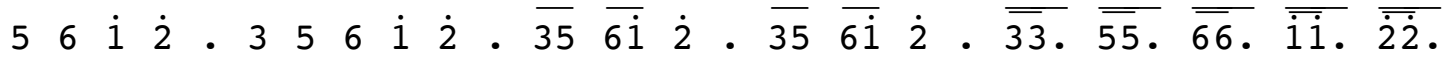

$\overline{\overline{33}} \cdot \overline{\overline{55}} \cdot \overline{\overline{66}} \cdot \overline{\overline{i \dot{1}}} \cdot \overline{\overline{2 \dot{2}}}$.

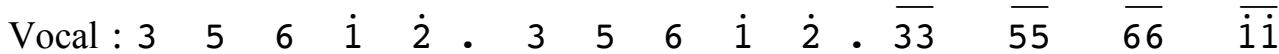

He he he he he he he he he he hehe hehe he hehe

$\overline{\dot{2}} \cdot \overline{33} \quad \overline{55} \quad \overline{66} \quad \overline{i \dot{1}} \quad \overline{\dot{2}} \quad \cdot \quad \overline{\overline{6 \dot{2}} \cdot \bar{i}} \overline{6 \dot{2}} \dot{i}$

hehe hehe hehe hehe hehe hehe ho

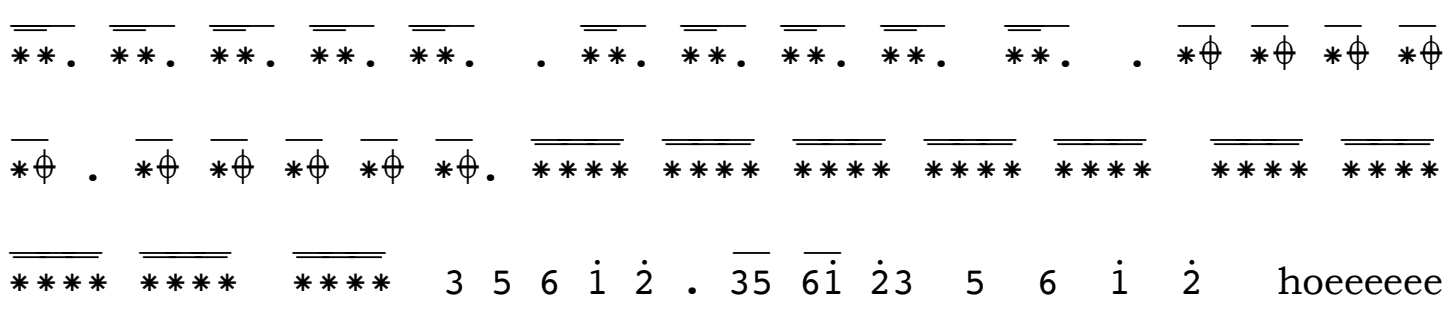

hoeeeeee tepuk tangan "plokplokplokplok memukul gong dengan motif pukulan $\overline{33}$. aah!!! . Ekspresi yang dimunculkan pemain • • selanjtnya muncul satu persatu motif adalah kecewa bahkan menangis karena tidak pukulan masing-masing instrumen gong ke arena ada respon dari teman-temannya maka si anak pertunjukan.

tersebut menumpahkan kekesalannya dengan

Kempul nada 3: [: $\overline{33}$ •

Kempul nada 5: [: $\left.\begin{array}{lllll}\overline{.5} & 5 & \overline{.5} & \text { • }\end{array}\right]$

Kempul nada 6: [:.$\quad \overline{66} \quad \overline{.6}$ 6:

Kempul nada $i:[: \quad . \quad * \overline{\bar{i}} \quad . \quad * \quad$ :]

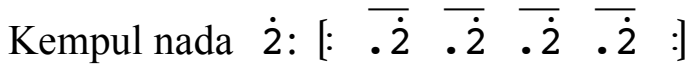


Dalam perjalanan ke arena pertunjukan ada pergerakan kaki seperti jalannya orang pincang. Hal ini dimaksudkan sebagai satu gambaran bahwa di dalam setiap kehidupan ini tidak ada yang sempurna pasti ada satu ketimpangan. Banyak orang tertawa, melecehkan, menghina dan sebagainya sebetulnya orang yang menertawakan, atau melecehkan adalah dia sendiri yang harus mawas diri apakah telah sempurna dalam hidupnya sebenarnya menertawai dirinya sendiri.
Transisi bagian ini ditandai dengan katakata "CIK WALANG KACIK" jawab "KOKO" kemudian kaki melangkah seperti prajurit berbaris sambil meletakkan kempul di atas plangkan. Kemudian sebagai aba-aba berhenti "CI WALANG KACI ..RUK .." CI WALANG KACI.. dijawab oleh anak yang sejak semula di atas stage "BERUK!" kemudian masing-masing improvisasi jalan dan membentuk formasi pola lantai berputar untuk motif ritme berikutnya. Ritmis pola hentakan kaki

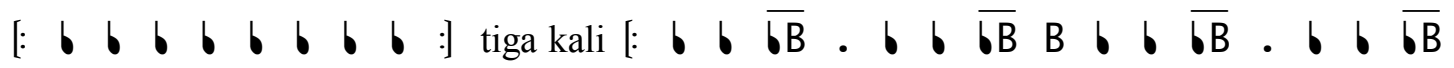

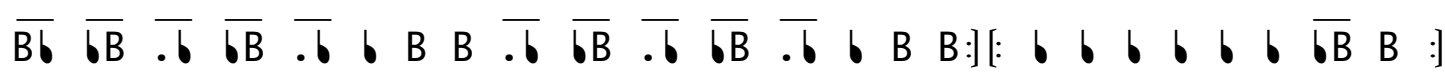

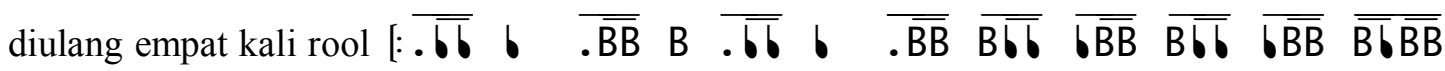

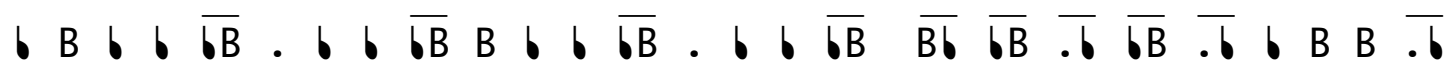

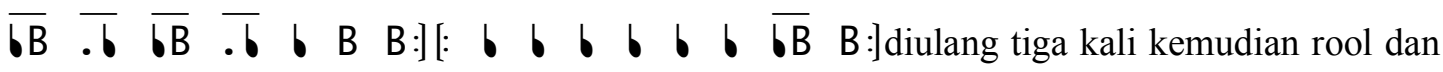
berubah ritmenya serta menggunakan kaki dan tepukan tangan $\begin{array}{llllllllll}\overline{\mathrm{Bt}} & \overline{\mathrm{tB}} & \overline{\mathrm{Bt}} & \overline{\mathrm{tB}} & \overline{\mathrm{Bt}} & \overline{\mathrm{tB}}\end{array}$ $\overline{\overline{. t .}} t$ : ] diulang empat kali dengan empat kali perubahan arah dan tiga kali dengan tempo cepat, dan diakhiri dngan teriakan "aduuuhhhh..." sambil jatuh telentang. Berhenti dan diam sesaat, satu orang pemain duduk sambil merintih aduuh...disusul berikutnya saling bersahut-sahutan. Selanjutnya dari kata-kata "aduuhh..." tersebut berubah menjadi pola ritme

[: $\overline{\mathrm{duh}} \mathrm{a} \overline{\mathrm{du} \mathrm{du}}:]$ diulang-ulang sambil berjalan menuju tempat instrument, dan berakhirnya ketika sudah berjajar satu baris dekat dengan instrumen gong, kemudian duduk serta memukul gong secara serentak ... selanjutnya pola ritme kaki tersebut diimitasikan ke dalam instrument gong.

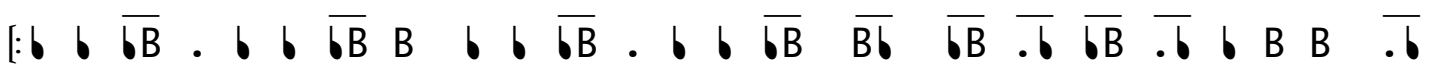

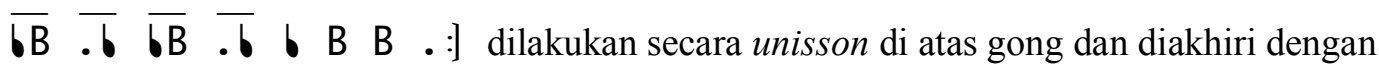

$$
\begin{aligned}
& \text { coda } \overline{. b} \overline{6 B} \overline{.6} \overline{6 B} \overline{.6} \quad \\
& 356356356,56 i 56 i 56 i, 6 i \dot{i} 6 i \dot{i} 6 i \dot{2}, \dot{2} \dot{i} 6 \dot{2} 6 \dot{2} i 6, \overline{6 \bar{i}} \dot{1} . \\
& 356 \dot{i} \dot{2}, \overline{35} \overline{6 \dot{i}} \dot{2}, \overline{35} \overline{6 \dot{i}} 2, \overline{36} 5 \overline{5 \dot{i}} 6 \overline{6 \dot{2}} \dot{1}, \overline{36} 5 \overline{5 \dot{i}} 6 \overline{6 \dot{2}} \dot{i} \text {, } \\
& \overline{\dot{2} \dot{i}} \overline{65} 3, \overline{35} \overline{6 \dot{i}} \overline{\dot{2}} \overline{65} 3, \overline{35} \overline{6 \dot{1}} \overline{\dot{2} \dot{1}} \overline{65} 3 \text {, rool }
\end{aligned}
$$




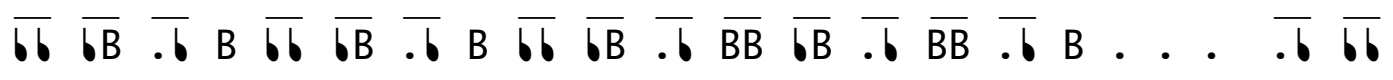

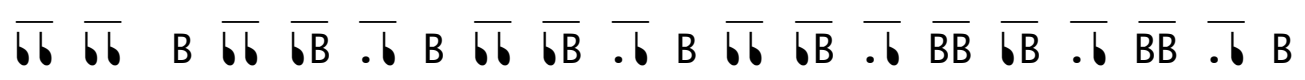

Motif tepuk tangan : [: t o t o t o t $\mathrm{p}$ t o t o t o $\mathrm{p}(\mathrm{p}):]$

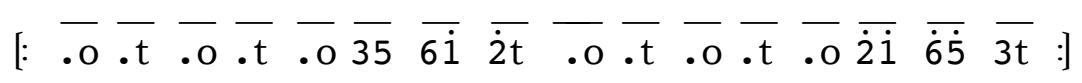

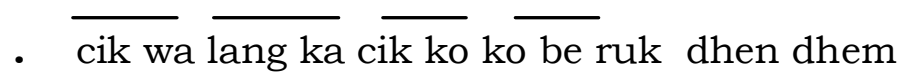

- $\overline{\text { cik wa }} \overline{\text { lang ka }} \overline{\text { cik ko }} \overline{\text { kobe }}$ ruk $\overline{\text {.dhem }} \overline{\text {. dhem dhem }}$

- $\overline{\text { cik wa }} \overline{\text { lang ka }}$ cik ko kobe ruk ruk [: $\overline{\text { cik wa }} \overline{\text { lang ka cik :] diulang } 3}$ kali

cik wa lang ka cik ko ko be ruk dhen dhem

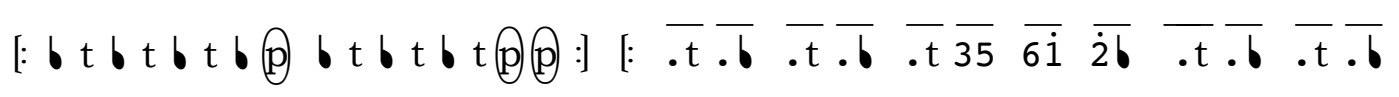

$\overline{. t} \overline{\dot{2} \dot{1}} \overline{\dot{6} \dot{5}} \overline{3 b}:] \quad[: \overline{c i k w a}$ lang ka cik :] diulang 3 kali

cik wa lang ka cik ko ko be ruk dhen dhem.

motif $1:[: \overline{b B} \overline{B b} \overline{. B} \quad \overline{b B} \overline{B b} \overline{. b} \quad B \quad:]$ unissono diulang 4 kali

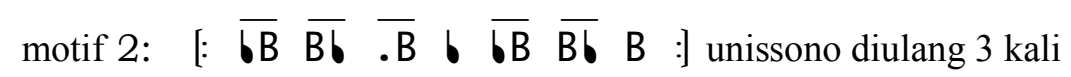

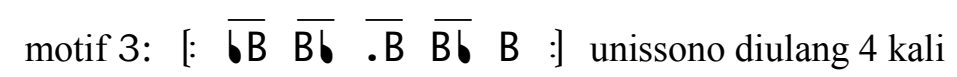

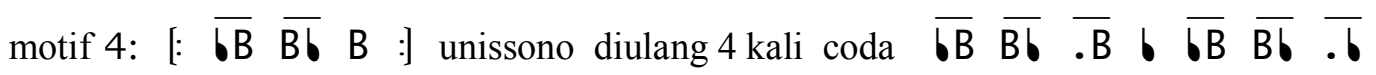

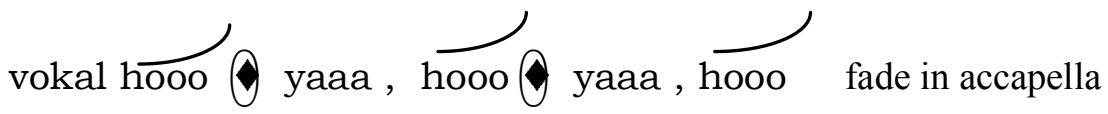

vokal 1 : [: gong gang gong gang :]

vocal 2 : [: $\overline{\text { gong e }} \overline{\text { gang e gong e }} \overline{\text { gang } \mathrm{e}}$ :]

vocal 3 : [: $\overline{\text { gong geng gung gang geng gang gong geng }}$ :] 
vocal 4 : [: gong gang gang $\cdot \overline{\text { gang gang }}:]$

vocal 5 : [: gong gang gang $\overline{\cdot \text { gang }} \overline{\cdot \text { gang }}$ :] diulang beberapa kali dengan

dinamika dan masing-masing pemain instrumen kempul dengan motif puklulan sama diberikan kebebasan improvisasi. Motif ini waktu pengucapan.

diimitasikan ke warna bunyi lain yakni ke dalam

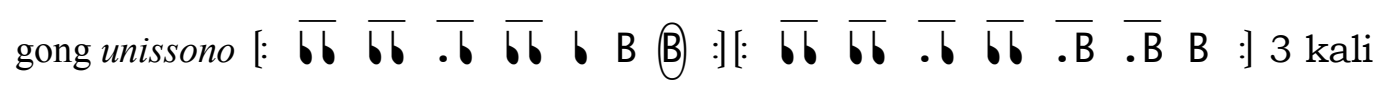

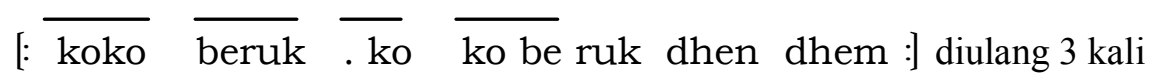

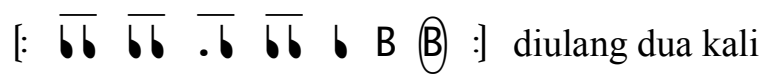

[: $\overline{\text { ko ko }} \overline{\text { beruk }} \overline{\text {. ko }} \overline{\text { kobe }}$ ruk dhen dhem :] diulang dua kali

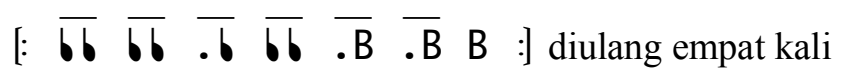

vokal : [: $\overline{\text { CIK WA }} \overline{\text { LANGKA }}$ CIK :]

gong :[: (B) (B) :] bagian ini diulang-ulang dengan dinamika dan

tempo semakin dipercepat hingga berakhir ketika ada transisi “ $\overline{\text { cik wa }} \overline{\text { lang ka }} \overline{\text { cik }}$

$\overline{\text { ko }} \overline{\text { kobe }}$ ruk" dilajutkan vokal

$\left[\begin{array}{lllllllllllll}1 & 2 & 3 & 5 & 6 & 5 & 3 & 2 & 1 & 2 & 3 & 5 & \overline{6 \overline{t t}}(\bar{B}) \cdot \overline{t t}\end{array}\right.$

Dem dem dem dem dem dem dem dem dem dem dem dem dem

$\begin{array}{lllllllllllllllllll}1 & 2 & 3 & 5 & 6 & 5 & 3 & 2 & 1 & 2 & 3 & 5 & \overline{6 B} & . \bar{B} & . \bar{B} & . \mathrm{B} & \mathrm{Dem}\end{array}$

dem dem dem dem dem dem dem dem dem dem dem dem

(B) :] Diulang dua kali

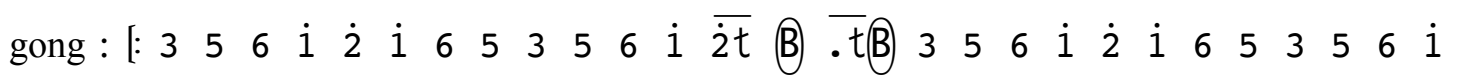

$\overline{t t} \overline{t t} \overline{t B} \quad t:$ diulang dua kali

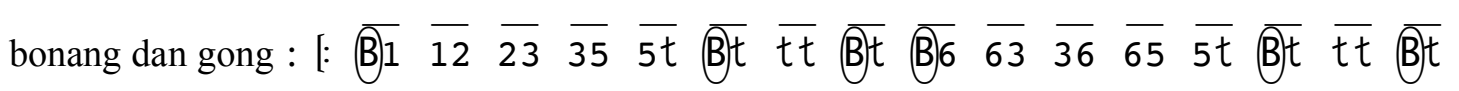

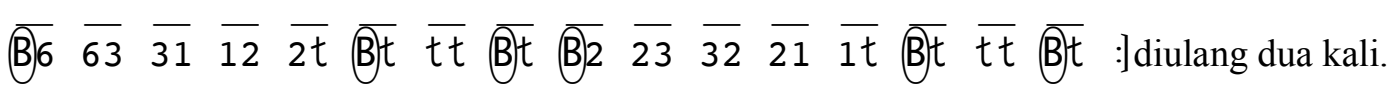




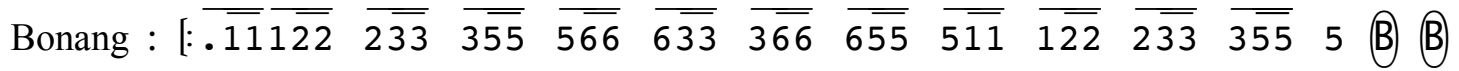

(BB) $\overline{. \overline{11}} \overline{122} \overline{2 \overline{33}} \overline{355} \overline{5 \overline{66}} \overline{6 \overline{633}} \overline{3 \overline{66}} \overline{\overline{655}} \overline{5 \overline{11}} \overline{122} \overline{2 \overline{33}} \overline{355} \overline{5 t} \overline{\mathrm{B} t} \overline{\mathrm{B} t} \overline{\mathrm{BB}}$

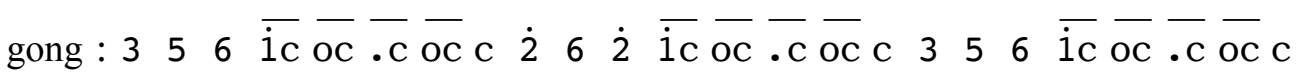

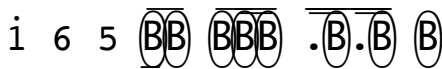

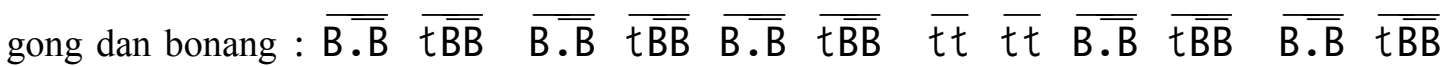

$\overline{B \cdot \bar{B}} \overline{t \overline{B B}} \overline{B B} \quad \overline{B B} \quad \overline{B \cdot \bar{B}} \overline{t \overline{B B}} \overline{B \cdot \bar{B}} \overline{t \overline{B B}} \overline{B \cdot \bar{B}} \overline{t \overline{B B}} \overline{\cdot t} \overline{\cdot t} \overline{B \cdot \bar{B}} \overline{t \overline{B B}} \overline{B \cdot \bar{B}} \quad \overline{t \overline{B B}}$

$\overline{B \cdot \bar{B}} \overline{t \overline{B B}} \overline{\cdot B} \overline{\cdot B} \overline{B \cdot \bar{B}} \overline{t \overline{B B}} \overline{B \cdot \bar{B}} \overline{t \overline{B B}} \overline{B t} \overline{t \overline{B B}} \overline{\overline{\cdot t \cdot t}} \overline{t B}$

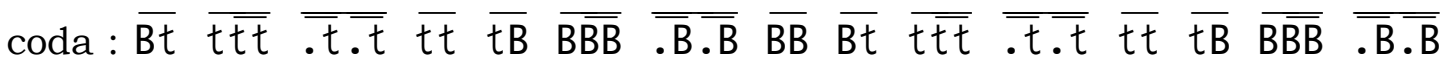

$\overline{B B} B \overline{\overline{t t} \overline{t t}} \overline{\overline{t t} \overline{t t}} \overline{\overline{t t} \overline{t t}} t \overline{\overline{B B} \overline{B B}} \overline{\overline{B B} \overline{B B}} \overline{\overline{B B} \overline{B B}} \quad B \overline{\overline{t t} \overline{t t}} \overline{\overline{t t} \overline{t t}} \overline{\overline{t t} \overline{t t}} t \overline{\overline{B B} \overline{B B}}$

$\overline{\overline{\mathrm{BB}} \overline{\mathrm{BB}}} \overline{\overline{\mathrm{BB}} \overline{\mathrm{BB}}} \quad \mathrm{B} \overline{\overline{\mathrm{tt}} \overline{t t}} \mathrm{t} \overline{\overline{\mathrm{BB}} \overline{\mathrm{BB}}} \quad \mathrm{B} \overline{\overline{\mathrm{tt}} \overline{t t}} t \overline{\overline{\mathrm{BB}} \overline{\mathrm{BB}}} \overline{\mathrm{Bt}} \overline{t \overline{\mathrm{BB}}} \overline{\overline{\cdot t} \cdot \bar{t}} \overline{t B} \overline{\mathrm{Bt}} \overline{t \overline{\mathrm{BB}}}$

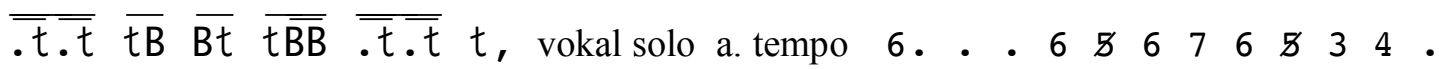

- $\begin{array}{llllll} & 3 & 2 & 1 & 3 & 3\end{array}$... improvisasi dari nada-nada tersebut, kemudian fade in vokal aksara

Jawa Hanacaraka [ . ha na . ca ra ka da ta sa wa la . pa dha . ja ya nya ma ga ba tha nga ] suara koor unisson dilakukan secara berulang-ulang. Berakhirnya pada bagian ini ketika satu orang pemain menangis dan berkata "Pak aku urung isa... mbok aku urung isa..." empat pemain segera menghampiri untuk menghibur agar berhenti menangis. Meskipun empat pemain tersebut telah membujuk untuk menghentikan tangisan akan tetapi anak tersebut tidak berhenti menangisnya bahkan semakin menjadi-jadi. Dan berakhirlah komposisi ini.

\section{Penutup}

Tumpang tindih sebagai satu karya musik merupakan ekspresi perasaan dalam diri penulis, dikembangkan dalam imajinasi dan diberi bentuk melaui rangkaian bunyi berdasar interpretasi personal. Inspirasi kreatif yang menstimulkan lahirnya karya ini adalah persoalan di antara fenomena yang ada dan ruang lingkup diri penulis. Nilai-nilai yang terkandung dalam huruf Jawa Hanacaraka beserta persoalan hidup mampu menggetarkan perasaan untuk selanjutnya diolah menjadi karya musik yang bersumber dari hal tersebut.

Proses panjang dan berliku-liku untuk dapat menciptakan komposisi yang bersumber pada huruf Jawa Hanacaraka dan pengalaman pribadi di saat kecil, menemukan sebuah kesimpulan sebagai berikut: 1) Pengolahan karya ini sebagai perwujudan dan pemahaman pribadi akan berbagai hal yang terkait dalam kehidupan manusia baik secara individu maupun sebagai makhluk sosial. 2) Penciptaan ini dimaksudkan sebagai penuangan dari pengalaman, pengetahuan dan wawasan yang didapatkan selama ini. 3) Belajar memahami dari segala aspek yang berbeda, mencoba menghubungkan dengan disiplin seni yang berbeda, adalah proses kreatif sehingga karya ini dapat terwujud. 4) Kesedihan, kegembiraan, 
dan kemarahan bercampuraduk sebagaimana proses perjalanan untuk dapat menciptakan sebuah karya musik, diwujudkan di dalam komposisi ini.

Semakin besar dan komplek karya seni semakin rumit dan semakin berat pula proses penyelesaiannya. Tetapi harus pula diingat di sini bahwa ukuran besar dan kompleknya sebuah karya seni tidak terletak pada ukuran matra, durasi dan berbelitnya sebuah komposisi. Komposisi yang pendek bisa jadi lebih menarik dari pada yang panjang tapi terkesan monoton dan membosankan.

\section{Kepustakaan}

Bandem, I Made. 1986. Prakempa Sebuah Lontar Gambelan Bali. Denpasar: ASTI Denpasar.

Djelantik, A.A.M. 2004. Estetika Sebuah Pengantar. Bandung : MSPI.

Djohan. 2009, Respons Emosi Musikal. Yogyakarta: Joglo Alit. Baik.

2003. Psikologi Musik. Yogyakarta: Buku

Endraswara, Suwardi. 2006. Mistik Kejawen Sinkretisme, Simbolisme dan Sufisme dalam Budaya Spiritual Jawa Yogyakarta: Narasi.
Hawkins, Alma M. 1991. Bergerak Menurut Kata Hati. Jakarta: MSPI.

Marianto, M. Dwi. 2007, "Relasi Luar Dalam Antara Seni Dan Metafora" dalam Jurnal Surya Seni Volume 4 No. 12007. Prize.

2006. Quantum Seni. Semarang: Dahara 2006. "Metode Pencip-taan Seni" dalam Jurnal Surya Seni Volume 3 No. 12006.

Prier, Karl Edmund. 1996, Ilmu Bentuk Musik. Yogyakarta: Pusat Musik Liturgi.

Ratna, Nyoman Kutha. 2007. Estetika Sastra dan Budaya. Yogyakarta: Pustaka Pelajar.

Riyadi, Slamet. 1996. Ha Na Ca Ra Ka (Kelabiran, Penyusunan, Fungsi, dan Makna). Yogyakarta: Yayasan Pustaka Nusatama.

Senen, I Wayan. 2002, Wayan Beratha Pembaharu Gamelan Kebyar Yogyakarta: Tarawang Press.

Smith, Jacqueline. 1985. Komposisi Tari. Yogyakarta: Ikalasti.

Sumardjo, Jakob. 2000. Filsafat Seni. Bandung: ITB.

Suryadi, Linus AG. 1993. Regol Megal-Megol Fenomena Kosmologi Jawa. Yogyakarta: Andi Offset. 